\title{
ANALISA KUALITAS DAN USABILITAS BERDASARKAN PERSEPSI PADA WEBSITE SHOPEE
}

\author{
Annisa Putri Ayudhitama1, Utomo Pujianto² \\ ${ }^{1,2}$ Teknik Elektro, Fakultas Teknik, Universitas Negeri Malang \\ 1ichadhitama@gmail.com, ${ }^{2}$ utomo.pujianto.ft@um.ac.id
}

\begin{abstract}
Abstrak
Website merupakan pilihan utama untuk mempromosikan sebuah produk yang ingin dijual, dengan adanya Website dapat mempermudah proses transaksi jual beli dan lebih menghemat waktu baik dari sisi penjual maupun pembeli. Website yang digunakan untuk toko online dan termasuk kedalam Website populer di Indonesia salah satunya yaitu Shopee. Shopee merupakan salah satu Website berbasis e-commerce yang berkembang pesat dan mampu bersaing dengan Website e-commerce lainnya yang ada di Indonesia seperti lazada, bukalapak atau tokopedia dan masih banyak lainnya. Shopee mengembangkan Website yang baik tetapi bagi penggunanya masih banyak persepsi yang muncul terutama untuk kualitas Website dari Shopee, karena kualitas sebuah Website seperti Shopee sangat berpengaruh pada minat jual beli. Usabilitas Website menurut Nielsen yaitu learnability, efficiency, memorability, errors, dan satisfaction. Usabilitas yang tinggi pada Website seperti Shopee mampu untuk menarik minat jual beli karena penggunaan Website yang dinilai mudah. Hasil dari paper ini berupa analisa kualitas dan usabilitas Website Shopee berdasarkan persepsi berbagai orang yang menggunakan Website Shopee, sehingga mampu membantu developer Website Shopee untuk memperbaiki Website yang dapat memberikan kepuasan bagi penggunanya.
\end{abstract}

Kata kunci : Kualitas website, Shopee, Website, Usabilitas

\section{Pendahuluan}

Penggunaan teknlogi internet saat ini seolah menjadi kebutuhan utama bagi masyarakat, bahkan anak-anak pun mulai memandang internet sebagai hal yang penting untuk mencari suatu informasi yang mereka butuhkan. Bagi remaja terkadang internet sangat penting bukan hanya untuk mencari informasi pelajaran tetapi mereka memanfaatkan internet untuk mengakses website dalam hal membeli pakaian, bahkan orang dewasa terutama pekerja akan selalu membutuhkan internet untuk mencari apapun yang mereka butuhkan sama halnya seperti mencari kebutuhan sandang yang ada di suatu website. Data dari Lembaga riset Marketeers menyebutkan jumlah pengguna internet khususnya di Indonesia selalu mengalami peningkatan dari tahun 2013 yang berjumlah $22 \%$ dibanding tahun sebelumnya, pengguna internet sebesar $47 \%$ yang ada di daerah Indonesia yaitu Jabodetabek, Bandung dan Yogyakarta menggunakan internet untuk melakukan aktivitas berbelanja online, hal itu disebutkan oleh riset Kementerian Komunikasi dan Informatika (2013).

Website merupakan sistem yang digunakan untuk menyebarkan suatu informasi, pada zaman teknologi seperti ini website banyak dimanfaatkan dalam kehidupan sehari - hari. Manfaat website dalam berbagai bidang sangat beragam, contohnya dalam bidang pendidikan website digunakan untuk website akademik, bidang kesehatan digunakan untuk sistem rekam medis, dan masih banyak lagi. Pada artikel ilmiah ini membahas website dalam bidang bisnis yaitu website toko online atau online shop, pentingnya penggunaan website untuk toko online yaitu mampu mempermudah proses transaksi jual beli karena bisa dilakukan kapanpun dan dimanapun, promosi produk menjadi lebih efisien dan efektif karena saat ini masyarakat cenderung mengakses internet sehari-harinya. Hal itulah yang menyebabkan website toko online berkembang pesat dan memiliki peluang pasar yang tinggi. Salah satu website toko online yang populer di Indonesia yaitu Shopee, Shopee bukan hanya menawarkan produk-produk yang dijual tetapi juga tampilan dari website Shopee harus diperhatikan karena menjadi faktor utama meningkatnya pembelian pelanggan.

Kualitas website toko online menjadi pondasi suksesnya suatu toko online, kualitas website dikatakan baik apabila tampilannya memliki gabungan elemen yang terdiri dari desain sistem, konten pada sistem, navigasi dan fungsional pada sistem sehingga layout website menjadi selaras serta seimbang. Suatu website bukan hanya website toko online haruslah bersifat simpel atau tidak rumit, tampilan harus menarik dan mudah digunakan agar kinerja dari website juga meningkat, selain itu suatu website harus memiliki konten yang tidak rumit atau ringkas serta gaya tulisan pada suatu website harus mudah dibaca sehingga pengguna merasa nyaman menggunakannya. 
Ketertarikan pengguna website bukan hanya dilihat pada kualitas website saja tetapi juga usabilitas yang dimiliki oleh sebuah website juga perlu diperhatikan. Apabila dalam suatu website toko online memiliki usabiitas yang tinggi maka akan menambah minat pelanggan untuk berbelanja di sisem informasi populer seperti Shopee. Hal terpenting dalam usabilitas sistem menurut Nielsen (1993) yaitu tingkat kemudahan penggunaan website (learnability), efisiensi website (efficiency), website memiliki navigasi yang mudah diingat oleh pengguna (memorability), tingkat kesalahan (errors rate), dan kepuasan pengguna terhadap website (satisfaction).

Pengguna atau pelanggan website Shopee di Indonesia sangatlah banyak sehingga memunculkan banyak persepsi tentang website Shopee baik dari kualitas website atau usabilitas. Ada sebagian pelanggan atau pengguna website Shopee yang mengatakan bahwa website Shopee masih memiliki kualitas yang belum sepenuhnya baik sehingga perlu pengembangan, ada yang mengatakan kualitas website Shopee sudah baik dan nyaman digunakan. Dari usabilitas website, ada yang mengatakan bahwa website Shopee harus diperbaiki dan berbagai macam persepsi penggunanya.

Oleh karena itu artikel ilmiah ini membahas tentang analisa kualitas dan usabilitas berdasarkan persepsi pada website Shopee, pada artikel ilmiah ini berisi berbagai masukan atau persepsi tentang kualitas dan usabilitas dari pengguna terhadap website Shopee. Hal ini bertujuan untuk membantu para developer Shopee atau sistem analis Shopee agar mengembangkan website Shopee dengan lebih baik sehingga memberikan kepuasan bagi penggunanya dalam mengakses atau menggunakan website Shopee. Jika website sudah diperbaiki menjadi lebih baik sesuai dengan masukan para pengguna maka keuntungan penjualan dari perusahaan Shopee dan juga para anggota toko online yang ada di Shopee mampu merasakan dampak meningkatnya penghasilan dengan banyaknya pengguna yang terus bertransaksi menggunakan website Shopee.

\section{Metodologi Penelitian}

Metodologi penelitian yang dilakukan yaitu studi pustaka, dengan mencari berbagai paper rujukan yang sesuai dengan penelitian tentang Shopee lalu menyimpulkan berbagai persepsi pengguna Shopee tentang kualitas dan Usability-nya. Berbagai macam persepsi pengguna tentang Shopee pada paper-paper tersebut menimbulkan berbagai keragaman pendapat dan metode untuk menganalisa kualitas dan Usability Shopee. Pada paper ini akan dijabarkan apa saja metode yang digunakan untuk menganalisa kualitas Shopee dan Usability-nya berdasarkan berbagai persepsi yang paling banyak muncul.

\subsection{Website}

Website merupakan cara suatu sistem informasi agar dapat ditampilkan di internet, siapapun dapat mengunjungi sebuah sistem informasi apabila sudah dijadikan sebuah website, $\mathrm{R}$. Harminingtyas (2014). Website digunakan untuk menampilkan segala informasi yang dibutuhkan sehingga dapat diakses melalui internet. Website sudah banyak diterapkan dalam berbagai bidang seperti bidang ekonomi dan bisnis atau yang biasa disebut dengan e-commerce. Website memiliki 2 sifat yaitu: 1) Sifat statis, website selalu berisi informasi yang tetap dan jarang diubah serta informasinya bersifat searah hanya dari pemilik website saja, contoh dari website statis yaitu profil perusahaan; 2) Sifat dinamis, website selalu berisi informasi yang berubah - ubah dan memiliki isi informasi yang interaktif atau 2 arah dari sisi pemilik website maupun pengguna website, contoh website dinamis yaitu facebook, instagram dan lainnya.

\subsection{Shopee}

Shopee merupakan salah satu perusahaan $e$ commerce atau situs jual beli online yang tergolong muda, shopee berkembang dengan sangat pesat terutama di Indonesia menyaingi situs jual beli online lainnya yang lebih dulu berkembangan di Indonesia. Shopee didirikan oleh seseorang yang bernama Chris Feng yang merupakan salah satu mahasiswa lulusan terbaik di Universitas Singapura pada tahun 2009 dikelola oleh Garena Group dan memiliki kantor pusat di Singapura, pada tahun 2015 Shopee diluncurkan untuk pertama kalinya di Singapura lalu berkembang ke negara lain termasuk Indonesia. Shopee masuk ke Indonesia pada tahun 2015 dan pada tahun 2018 sudah meraih 1,5 juta transaksi dalam 24 jam, hal tersebut memecahkan rekor baru bagi situs jual beli online di Indonesia, R. Mardatilla, et al (2017). Shopee menjual berbagai macam produk yang selalu dibutuhkan oleh masyarakat yaitu pakaian, perlengkapan rumah tangga, aksesoris, peralatan elektronik, mainan, peralatan otomotif, produk kecantikan dan kesehatan dan masih banyak lainnya. Penawaran terbaik dari Shopee yaitu gratis ongkos pengiriman se-Indonesia sehingga membuat Shopee begitu diminati dan membawa pengalaman belanja online yang baru, shopee telah memfasilitasi para penjual sehingga bisa berjualan dengan mudah. Shopee memiliki aplikasi baik mobile maupun website yang bisa diakses dimanapun dan kapanpun, sehingga antara penjual dan pembeli mampu melakukan transaksi tanpa dibatasi oleh tempat dan waktu. Shopee merupakan e-commerce yang tidak hanya berkembang di Indonesia tetapi lebih dulu berkembang di negara tetangga seperti Singapura, Vietnam, Thailand, Filipina, Taiwan dan Malaysia. Pada tahun 2016 Shopee telah berhasil membukukan total nilai transaksi berjumlah USD 1,8 miliar di 
kawasan Asia Tenggara dan Taiwan, F. Margaretha (2017). Di Indonesia sebelum adanya shopee telah ada aplikasi jual beli online yang juga banyak diminati seperti Tokopedia, OLX, Lazada, Bukalapak dan lainnya. Shopee sebagai pendatang baru situs jual beli online memiliki ciri khas tersendiri sehingga mampu menarik banyaknya penjual dan pembeli.

Keunnggulan shopee sebagai pendatang baru situs jual beli online yang mampu menyaingi berbagai situs jual beli online lainnya yaitu (1) Dengan berbelanja di Shopee, pembeli akan mendapatkan tawaran berbagai promo dan diskon yang mampu menjadi daya tarik, (2) Berbagai kategori produk telah lengkap disediakan oleh Shopee, sehingga para penjual dapat menjual jenis-jenis barangnya serta pembeli mampu mendapatkan barang-barang yang diinginkan secara mudah, (3) Keunggulan Shopee yang paling utama yaitu menawarkan gratis ongkis pengiriman barang ke seluruh Indonesia dengan ketentuan yang telah ditetapkan, (4) Shopee menyediakan fasilitas yang mampu mendekatkan interaksi penjual dan pembeli dalam bertransaksi yaitu melalui chat, (5) Shopee menyediakan penjualpenjual yang memiliki jarak terdekat dengan calon pembeli, (6) Dengan belanja di Shopee, barang belanja yang kita beli akan sampai ke tempat kita dalam waktu yang lebih cepat.

Selain keunggulan, Shopee juga memiliki berbagai kekurangan dari segi fasilitas yaitu (1) Untuk mendapatkan tawaran gratis ongkos pengiriman seluruh Indonesia mengharuskan pembeli harus menyetujui syarat dan ketentuan yang mungkin merepotkan, (2) Gambar yang ditampilkan terkadang tidak sama dengan barang yang dikirimkan, (3) Respon para penjual dalam menjawab chat dari pembeli dinilai cukup lama, (4) Terkadang Shopee sulit diakses pada jam - jam tertentu, (5) Banyak para penjual yang melakukan kecurangan sehingga membuat para pembeli merasa dirugikan.

Walaupun tergolong sebagai situs jual beli online termuda tetapi nyatanya Shopee mampu mendongkrak dan mampu menyaingi situs jual beli online lainnya karena Shopee mengedepankan strategi yang terbukti menjadikan Shopee sangat maju. Adapun strategi Shopee yaitu (1) Dalam hal pemasaran, Shopee memiliki teknik yang baik dengan mengikuti perkembangan zaman sekarang atau yang biasa kita kenal dengan tren. Shopee memiiki teknik pemasaran lagu Baby Shark yang diganti liriknya menjadi "Di Shopee pi pi pi pi pi", sehingga masyarakat akan lebih mudah mengingat Shopee hanya dengan lagu Baby Shark, (2) Aplikasi Shopee dibuat baik dalam bentuk website maupun aplikasi mobile sehingga bisa diakses secara mudah, (3) Shopee menawarkan promo berupa gratis ongkos pengiriman yang menjadi daya tarik utama dan berhasil menjadikan Shopee sebagai situs belanja online terdepan, (4) Harga produk yang ditawarkan sangat terjangkau, sebagai pembeli hal yang paling diperhatikan adalah harga dimana harga menjadi faktor utama dalam membeli suatu produk. Shopee menawarkan garansi harga termurah, uang kembali $2 \mathrm{x}$ lipat. Hal tersebut membuat para pembeli tidak ragu untuk belanja di Shopee karena harga produkproduk di Shopee termurah dibanding situs jual beli online lainnya, (5) Target pasar yang digunakan shopee sangat tepat yaitu perempuan, karena perempuan merupakan pengguna situs jual beli online yang sangat mendominasi. Oleh karena itu Shopee lebih mengedepankan penjualan produk yang dibutuhkan oleh perempuan.

\subsection{Kualitas Website}

Kualitas website merupakan hal utama yang menjadi sebuah perhatian khusus, dimana jika sebuah bisnis menggunakan website dan memiliki kualitas yang baik maka membantu bisnis tersebut menjadi lancar. Website yang berkualitas baik memiliki tampilan dengan layout yang selaras dan seimbang yang menggabungkan beberapa elemen penting yaitu desain, konten, navigasi dan fungsional, T. P. Darmawan, et al (2017). Bukan hanya tampilan tetapi kualitas website dinilai dari cara kerja website dimana sebuah website harus user friendly, tidak rumit dan harus menarik supaya pengguna merasakan kenyamanan dalam menggunakan website tersebut. Website yang memiliki konten ringkas dan penggunaan font yang mudah dibaca, navigasi sistem mudah dan pengguna mudah menemukan apapun yang dicari, hal tersebut juga menjadi penyebab mengapa website dikatakan memiliki kualitas yang baik.

Metode untuk pengukuran suatu kualitas website yaitu metode WebQual, metode ini menggunakan pengukuran penelitian dengan 3 kategori variabel yang dijadikan acuan kepuasan pengguna website terhadap kualitasnya. Adapun 3 variabel yang digunakan dalam metode WebQual adalah kegunaan website (usability), kualitas informasi (information quality), kualitas interaksi layanan pada website (service interaction). Ketiga kategori tersebut memiliki dimensi yang akan dijabarkan pada tabel berikut, E. M. Landaoe, et al (2018).

Tabel 1. Dimensi Variabel WebQual

\begin{tabular}{|c|l|l|}
\hline No & \multicolumn{1}{|c|}{ Dimensi } & \multicolumn{1}{c|}{ Indikator } \\
\hline 1 & Kegunaan & Mudah dalam \\
& (Usablity) & mengoperasikan \\
& & website, \\
& & Interaksi dengan \\
& & website mudah \\
& & dipahami, \\
& & Navigasi website \\
& & mudah, \\
& & Website mudah \\
& & digunakan, \\
& & Website memiliki \\
& & tampilan yang menarik, \\
\hline
\end{tabular}




\begin{tabular}{|c|c|c|}
\hline No & Dimensi & Indikator \\
\hline & & $\begin{array}{l}\text { Desain website sesuai } \\
\text { dengan tipe website, } \\
\text { Website meyakinkan } \\
\text { dan kompeten, } \\
\text { Website mampu } \\
\text { menumbuhkan } \\
\text { pengalaman yang } \\
\text { positif bagi pengguna }\end{array}$ \\
\hline 2 & $\begin{array}{l}\text { Kualitas } \\
\text { informasi } \\
\text { (information } \\
\text { quality) }\end{array}$ & $\begin{array}{l}\text { Informasi yang } \\
\text { diberikan akurat, } \\
\text { Informasi yang } \\
\text { diberikan terpercaya, } \\
\text { Informasi yang } \\
\text { diberikan tepat waktu, } \\
\text { Informasi yang } \\
\text { diberikan relevan, } \\
\text { Informasi yang } \\
\text { diberikan mudah } \\
\text { dipahami, } \\
\text { Informasi yang } \\
\text { diberikan detail } \\
\text { Informasi yang } \\
\text { diberikan sesuai } \\
\text { dengan format }\end{array}$ \\
\hline 3 & $\begin{array}{l}\text { Interaksi } \\
\text { layanan(service } \\
\text { interaction) }\end{array}$ & $\begin{array}{l}\text { Reputasi website baik, } \\
\text { Pengguna merasa aman } \\
\text { dalam menyelesaikan } \\
\text { transaksi, } \\
\text { Pengguna merasa aman } \\
\text { memberikan informasi } \\
\text { pribadi, } \\
\text { Website mampu } \\
\text { menjamin terjaganya } \\
\text { informasi pribadi, } \\
\text { Website memiliki citra } \\
\text { yang baik } \\
\text { Website mampu } \\
\text { mempermudah } \\
\text { komunikasi } \\
\text { Pengguna merasa yakin } \\
\text { bahwa produk yang } \\
\text { dipesan akan dikirim } \\
\text { sesuai dengan } \\
\text { kesepakatan }\end{array}$ \\
\hline
\end{tabular}

Selain pengukuran menggunakan WebQual, suatu website dikatakan memiliki kualitas yang baik jika memiliki kualitas layanan atau Service Quality yang mengadaptasi dari 5 dimensi model Kasim Abdullah. Adapun 5 dimensi tersebut yaitu (1) Ease of Use, (2) Web Design and Layout, (3) Responsiveness, (4) Personlization, (5) Assurance. Dimensi service quality akan berpengaruh besar pada Kepercayaan (Trust), mulut ke mulut (Word of Mouth) dan niat (Intention). Metode analisis kualitas salah satunya yaitu IPA (Importance Performance Analysis), IPA digunakan untuk menganalisis website terutama tentang kualitas layanan. Dimensi kepentingan pada IPA akan menunjukkan pentingnya atribut kualitas menurut pengguna.

\subsection{Usability Website}

Usability merupakan penilaian tingkat kemudahan suatu sistem agar dapat digunakan oleh pengguna untuk mendapatkan tujuan tertentu dengan efektifitas, efisiensi serta rasa puas saat menggunakan website tersebut, Y. Ichsani (2018). Adapun tujuan dari Usability adalah (1) Mampu memberikan informasi secara jelas dan singkat kepada pengguna, (2) Mampu memberikan pilihan kepada pengguna melalui cara yang mudah dimengerti, (3) Mampu mengurangi bahasa ambigu dalam website, (4) Mampu menempatkan hal penting pada website. Usability pada website biasanya sering digunakan pada situs belanja online atau e-commerce karena website belanja online berhubungan langsung dengan pelanggan, apabila website-nya tidak mudah digunakan dan tidak menarik maka calon pelanggan tidak berminat untuk membeli produk di situs tersebut. Kriteria Usability website menurut Nielsen (1994) yaitu:

1. Learnability, salah satu kriteria yang mampu mengukur tingkat kemudahan suatu website untuk dipelajari dan digunakan terutama bagi pengguna yang baru pertama kali mengunjungi website tersebut

2. Efficiency, salah satu kriteria yang mampu mengukur tingkat kemampuan pengguna saat menggunakan situs tersebut

3. Memorability, salah satu kriteria yang mampu melihat kemudahan para pengguna saat menggunakan sistem walaupun sistem tersebut telah lama tidak dikunjungi

4. Errors, salah satu kriteria yang mampu menilai terjadinya kesalahan yang dilakukan pengguna

5. Satisfaction, salah satu kriteria yang mampu dirasakan pengguna seperti kemudahan, kenyamanan dan mampu memberikan kepuasan saat menggunakan website tersebut

\section{Hasil dan Pembahasan}

Sudah banyak penelitian yang membahas tentang kualitas dan Usability website Shopee, hasil studi pustaka dari penelitian-penelitian yang ada berbeda-beda karena para peneliti menggunakan berbagai macam metode untuk mencari tahu hasil kualitas maupun Usability pada sistem belanja online seperti Shopee. Pada penelitian yang dilakukan oleh Noorliana Rahmah memperoleh hasil analisa website Shopee berdasarkan persepsi mahasiswa khususnya di Surabaya dengan membagi beberapa aspek, N. Rahmah (2016). Aspek pertama yaitu tentang warna tampilan website Shopee yang memiliki warna cerah oranye dan putih dirasa sesuai dengan penglihatan dan menarik untuk dilihat sehingga calon pembeli 
tidak merasa bosan karena adanya pemisahan warna latar depan dan warna latar belakang, aspek kedua yaitu gaya tulisan formal yang digunakan pada website Shopee menunjukkan bahwa Shopee dibuat secara tidak sembarangan dan termasuk lembaga yang resmi dan gaya tulisan terkesan modern serta memiliki tingkat kekonsistenan sehingga mudah untuk dibaca dan tidak membuat mata pembacanya letih, aspek ketiga yaitu deskripsi informasi produk yang ditampilkan di website Shopee mudah dipahami serta calon pelanggan mampu untuk melihat informasi produk yang akan dibeli secara lengkap dan adanya fitur pencarian atau searching telah disediakan untuk memudahkan produk yang diinginkan dapat ditemukan, aspek keempat yaitu penilaian produk berupa bintang atau tulisan atau gambar yang ada di kolom komentar website Shopee sangat tepat dan berpengaruh karena ternyata calon pembeli akan melihat penilaian tentang produk sebelum membelinya dan calon pembeli akan merasa percaya bahwa Shopee adalah toko online yang terpercaya.

Analisa Kualitas website Shopee menggunakan metode IPA (Importance Performance Analysis) menghasilkan 4 kuadran yaitu kuadran A merupakan kuadran yang berisi atribut prioritas utama menurut pengguna dan harus segera diperbaiki Shopee agar website Shopee menjadi lebih baik lagi, akan tetapi website Shopee belum sesuai dengan harapan konsumen. Adapun atribut yang ada pada kuadran A adalah website Shopee mudah digunakan, website Shopee mudah dipahami, website Shopee mudah untuk navigasi, tampilan website Shopee menarik, website Shopee memberikan informasi produk secara akurat, website Shopee memberikan informasi yang dipercaya, website Shopee memperbarui informasi setiap produk dengan tepat waktu, website Shopee memberikan informasi harga yang dijual, dan keamanan data pribadi konsumen. Kuadran B merupakan kuadran yang berisi atribut yang harus dipertahankan oleh Shopee karena sudah sesuai dengan harapan konsumen. Adapun atributnya adalah kemudahan akses website Shopee, desain website Shopee yang sesuai dengan website $e$ commerce pada umumnya, website Shopee mampu memberikan informasi produk dengan format yang benar, website Shopee memiliki reputasi yang baik, pelayanan secara personal, calon pembeli merasa menjadi bagian dari komunitas. Kuadran C merupakan kuadran yang berisi atribut yang harus dikurangi karena dianggap tidak begitu penting dan memiliki kinerja yang kurang baik pada website Shopee yaitu memberikan informasi barang yang mudah dipahami. Kuadran D merupakan kuadran yang berisi atribut yang melebihi harapan dari pengguna sehingga dapat ditiadakan agar biaya lebih efisien yaitu loading penyajian website Shopee cepat, informasi spesifikasi produk pada website Shopee ditampilkan dengan rinci, keamanan dalam bertransaksi dan mudah dalam berhubungan dengan perusahaan.

Pada penelitian yang dilakukan oleh Mahir Pradana pada tahun 2018, ia menggunakan metode IPA (Importance Performance Analysis) dimulai dengan mengumpulkan data melalui kuisioner yang disebarkan ke 100 responden yang terbagi ke pria sebesar $32 \%$ dan wanita $68 \%$ pengguna Shopee. Hasilnya menunjukkan bahwa tingkat kualitas website Shopee sudah sesuai dengan harapan pengguna, berdasarkan 4 kuadran IPA yang menjadi atribut prioritas utama yang harus diperbaiki yaitu atribut kuadran I. Terdiri dari desain sistem, informasi yang relevan, informasi dengan detail yang benar dan keamanan informasi pribadi pada website Shopee, $\mathrm{M}$. Ichsan (2018). Desain website lebih diperhatikan, website Shopee harus menyajikan informasi yang mampu dipercaya oleh pengguna serta peningkatan informasi pribadi pada website Shopee agar pengguna mampu merasa aman menggunakan website. Jika Shopee memperbaiki kualitas tersebut maka kualitas website akan meningkat karena telah sesuai dengan keinginan pengguna. Penelitian yang dilakukan oleh Widya Sastika pada tahun 2017 memperoleh hasil analisa kualitas website Shopee menggunakan IPA dengan 4 kuadran yaitu tingkat harapan pengguna dari website Shopee sebesar $86,92 \%$ yang terdiri dari efficiency, fulfillment, reliability, privacy, responsiveness, contact, compentation. Tetapi tingkat kenyataan dari website Shopee sebesar 68,78\%, W. Sastika (2017). Hal tersebut menunjukkan bahwa website Shopee belum sepenuhnya menerapkan harapan dari pengguna sehingga kualitas Shopee dikatakan belum begitu baik. Penelitian yang dilakukan oleh Latifah Zulfa pada tahun 2018 memperoleh hasil bahwa kualitas situs website sangat berpengaruh positif pada minat keputusan pembelian suatu produk di website belanja online seperti Shopee. Artinya yaitu apabila kualitas website Shopee semakin baik maka akan semakin tinggi pula minat para konsumen untuk membeli produk di Shopee, L. Zulfa, et al (2018).

Kualitas website Shopee selain menggunakan metode IPA, dapat digunakan metode lain yaitu WebQual 4.0 dengan melihat indikator yang sudah dijabarkan di bab metodologi penelitian dan memperoleh hasil diantaranya:

1. Kegunaan website Shopee masuk dalam kategori baik yaitu indikator "Mudah dalam mengoperasikan website" mendapatkan tanggapan tinggi, sedangkan indikator "Website meyakinkan dan kompeten" mendapat tanggapan rendah. Hal ini membuktikan bahwa Shopee belum bisa meyakinkan pengguna website akan kompetensinya.

2. Kualitas website Shopee masuk dalam kategori baik yaitu indikator "Informasi yang diberikan mudah dipahami” mendapatkan tanggapan tinggi, sedangkan indikator "Informasi yang 
diberikan terpercaya" mendapat tanggapan rendah. Hal ini membuktikan bahwa Shopee belum bisa meyakinkan pengguna percaya akan informasi yang diberikan.

3. Interaksi layanan website Shopee menjadi faktor kuat yang mempengaruhi keputusan pembeli yaitu indikator "Website memiliki citra yang baik" mendapatkan tanggapan tinggi, sedangkan indikator "Website mampu menjamin terjaganya informasi pribadi" mendapat tanggapan rendah. Hal ini membuktikan bahwa Shopee belum bisa meyakinkan pengguna percaya akan terjaganya informasi pribadi.

Selain kualitas, pada penelitian ini juga akan dibahas analisa tentang Usability website Shopee. Pada penelitian yang dilakukan oleh Gilang Hamzah Akbar pada tahun 2017 memperoleh hasil tentang masalah Usability yang ada pada ketiga website $e$ commerce, salah satunya website Shopee, G. H. Akbar (2017). Adapun masalah-masalah yang dikeluhkan penggunanya yaitu adanya kode captcha sehingga membuat proses pembuatan akun baru terasa sulit, pada setiap produk hanya ditampilkan kode warna sehingga pengguna merasa kesulitan karena tidak semua orang mengetahui kode warna, tampilan website penuh dengan gambar, pada website memiliki pop-up iklan, fitur filter pada website tersembunyi, brand produk pada website sulit ditemukan, tulisan pada website berukuran kecil. Dengan adanya permasalahan tersebut peneliti memberikan rekomendasi untuk memperbaiki masalah website Shopee yaitu menghapus kode captcha dalam pembuatan akun, menampilkan warna bukan hanya kode warnanya pada semua produk, mengurangi gambar di setiap halaman website, mengurangi pop-up iklan, menampilkan fitur filter, merk diurutkan sesuai abjad, ukuran huruf atau font diperbesar.

Evaluasi Usability menurut Nielsen memiliki banyak prinsip yaitu visibiltas status sistem, kesesuaian antara sistem dan dunia nyata, kontrol dan kebebasan pengguna, konsistensi dan standar, pencegahan kesalahan, pengakuan daripada penarikan kembali, fleksibilitas dan efisiensi penggunaan, desain estetika dan minimalis, membantu mengenali pengguna, mendiagnosis dan memulihkan dari kesalahan, bantuan dan dokumentasi (10 Usability Heuristics by Nielsen; Lazada and Shopee Review.). Adapun rangkuman Usability pada website Shopee yaitu:

\section{Main menu}

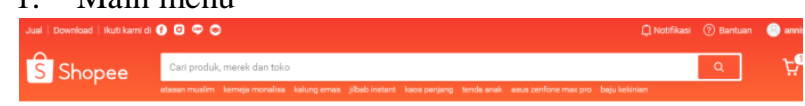

Main menu pada website Shopee terdiri dari login, bantuan, notifikasi, keranjang belanja, jual, download, ikuti kami, pencarian, beberapa kategori produk. Ketika salah satu menu di klik maka akan langsung menampilkan halaman dari menu tersebut, contohnya ketika kita mengklik menu login maka akan langsung menampilkan halaman login. Hal tersebut memudahkan pengguna karena ditunjukkan secara langsung halaman dari menu yang diklik.

2. Flash sale timer

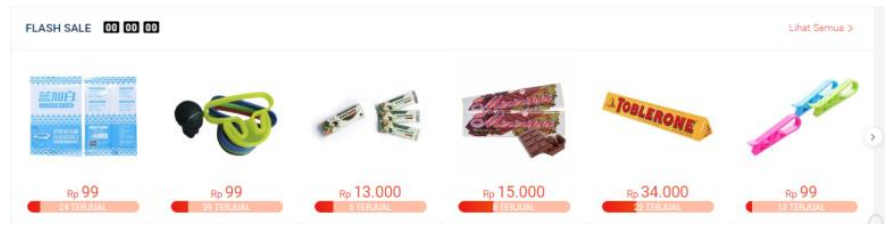

Shopee memiliki fitur penjualan cepat yang menjual berbagai macam produk dengan diskon besar-besaran, Shopee menambahkan penghitung waktu mundur untuk flash sale. Hal tersebut digunakan untuk menunjukkan kepada calon pembeli berapa waktu yang tersisa untuk pembelian produk flash sale.

3. Pencarian produk

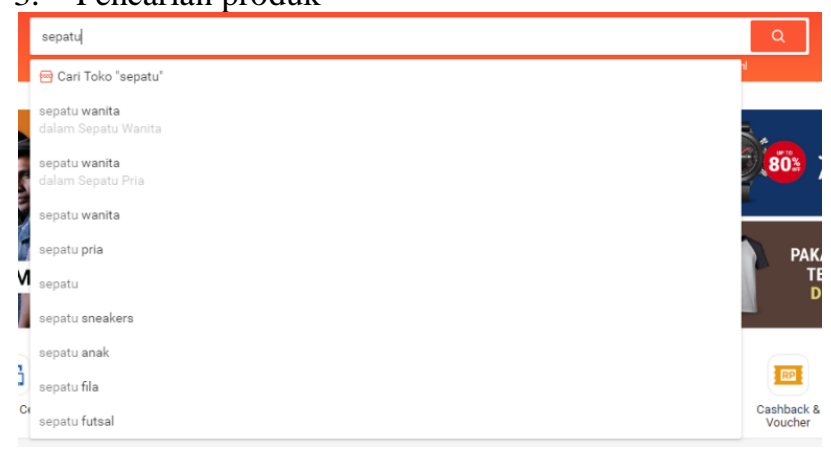

Fitur pencarian produk pada Shopee terletak di tengah atas pada main menu, fitur ini digunakan untuk mempermudah calon pembeli dalam mencari produk yang mereka inginkan karena mampu mempersempit pencarian. Fitur pencarian diberikan warna putih dan button pencarian warna oranye, hal tersebut bermanfaat bagi pengguna sehingga mampu membedakan background dengan fitur pencarian.

4. Keranjang belanja

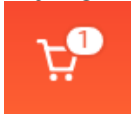

Fitur keranjang belanja ditandai dengan ikon keranjang dan terletak di kanan atas pada main menu, hal tersebut memudahkan pengguna untuk mengetahui bahwa ikon tersebut adalah ikon keranjang belanja yang digunakan untuk menyimpan barang - barang yang ingin dibeli, apabila calon pembeli memasukkan produk ke dalam keranjang belanja maka di pojok ikon akan ditambahkan jumlah produk yang dimasukkan ke dalam keranjang belanja.

5. Representasi ikon

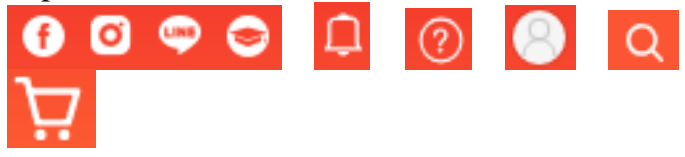


Representasi ikon yang digunakan Shopee sangat mudah dipahami karena sama dengan objek yang ada di sekitar, seperti ikon facebook, ikon instagram, ikon line, ikon toga, ikon notifikasi, ikon bantuan, ikon user, ikon pencarian, ikon keranjang. Ikon tersebut sudah familiar dan mudah dimengerti oleh pengguna

\section{Penggunaan bahasa}

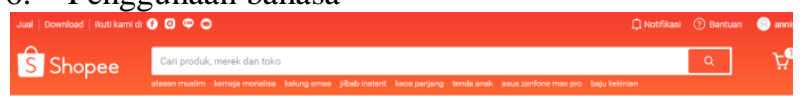

Penggunaan bahasa pada Shopee tergantung dimana negara tempat calon pembeli tinggal, seperti di Indonesia maka Shopee akan memberikan akses Shopee Indonesia yang memiliki bahasa Indonesia sehingga calon pembeli merasa nyaman mengakses website Shopee.

7. Variasi produk

NF - BEST SELLER JUMPSUIT HANI

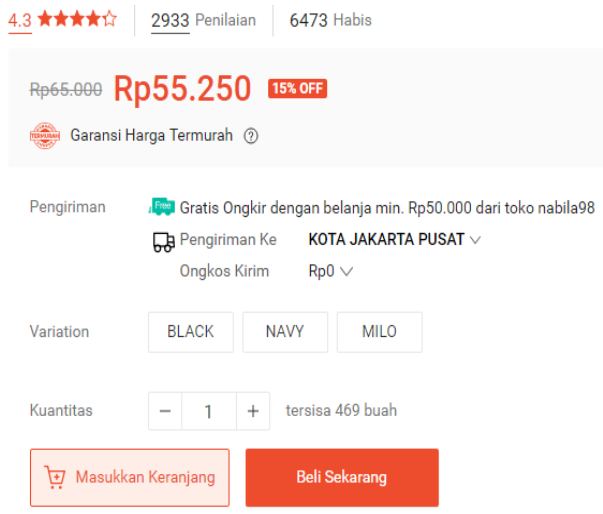

Ketika calon pembeli ingin memesan atau menambahkan produk yang mereka inginkan ke keranjang, maka mereka akan memikirkan hal yang paling penting selain harga yaitu variasi warna produk. Shopee telah menyediakan fitur variasi warna yang tersedia pada setiap produk sehingga mampu membantu calon pembeli untuk memilih produk dengan warna yang diinginkan.

8. Konsistensi warna

Shopee memiliki identitas warna oranye dan putih yang digunakan di seluruh halamannya, konsisten warna yang dimiliki Shopee membuat pengguna tidak bingung. Warna putih merupakan warna umum yang digemari pengguna dan warna oranye mampu menarik perhatian penggunanya.

9. Pita produk

Beberapa produk yang ada di Shopee pasti memiliki ciri khas dengan warna pita, contohnya seperti gambar diatas memiliki pita berwarna oranye dengan tulisan "Star Seller" serta tanda centang yang berarti produk tersebut dijual oleh seller yang memiliki apresiasi dari Shopee sebagai seller aktif dan mampu melayani pembeli dengan baik, sedangkan pita berwarna kuning menandakan diskon produk.

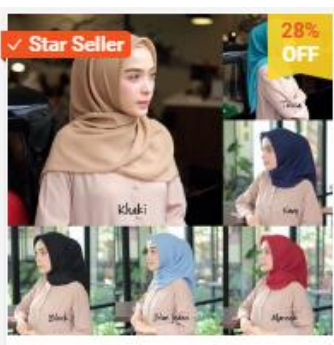

Bella Square "warna part 1"

Rp13.000 528134 Terjual

10. Label produk

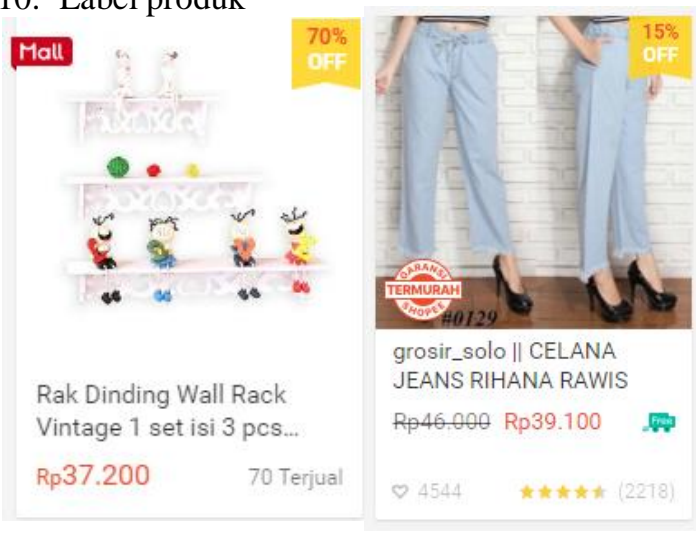

Shopee juga menyediakan label untuk beberapa produk seperti label dengan warna merah yang memiliki teks "Mall" yang berarti produk tersebut juga dijual pada shopee mall. Label dengan warna oranye yang memiliki teks "Garansi harga termurah" yang berarti produk tersebut memiliki harga termurah diantara produk yang sama, sedangkan ikon truk berwarna tosca yang berarti produk memberikan pengiriman gratis dengan transaksi minimum.

11. Stok produk

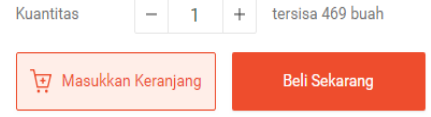

Shopee menyediakan fitur stok pada masingmasing produk hal tersebut memberikan kemudahan bagi calon pembeli untuk mengetahui stok produk dan pengguna mampu menambah jumlah produk yang ingin dibeli dengan menekan tombol + .

\section{Checkout}

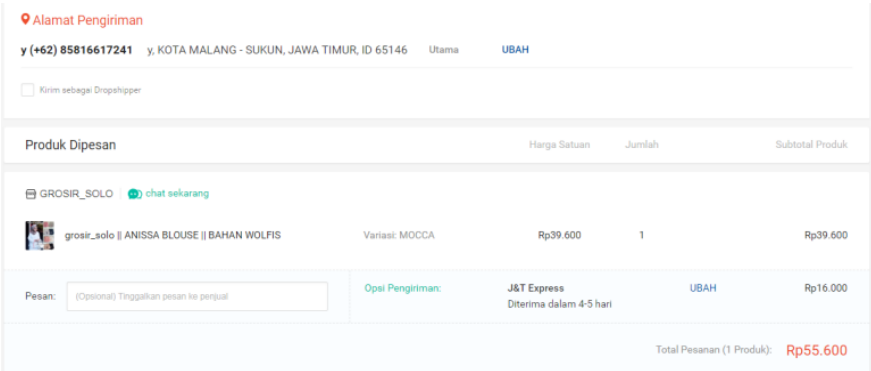

$\mathrm{H}$ a 1 a $\mathrm{m}$ a $\mathrm{n} \mid \mathbf{6 7}$ 
Usability untuk transaksi pada Shopee dimulai dari halaman checkout. Shopee menyediakan halaman checkout ketika pembeli menekan tombol "Beli Sekarang" pada produk yang ingin dia beli, halaman checkout sangat bermanfaat bagi calon pembeli karena berguna untuk mengecek alamat, produk yang dipesan, melihat biaya pengiriman produk dan memilih opsi pembayaran.

13. Pembayaran

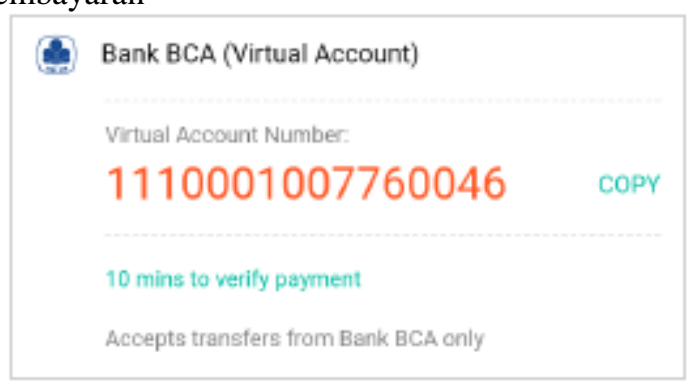

Proses pembayaran di Shopee apabila melalui mobile banking akan mendapatkan nomor akun virtual yang cukup panjang sehingga memungkinkan pengguna mengalami kesalahan dalam mengetik, untuk itu Shopee memberikan pilihan untuk menyalin angka tersebut atau copy sehingga pengguna hanya perlu menyalinnya dan mampu meminimalisir terjadinya kesalahan.

14. Fitur bantuan
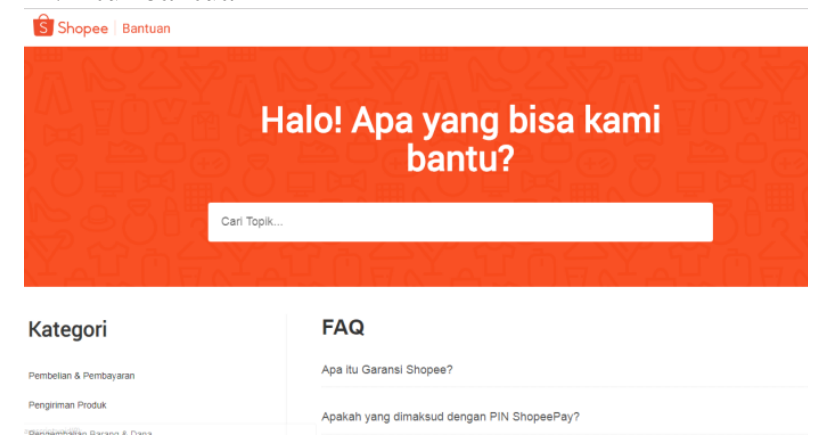

Shopee menyediakan fitur bantuan yang sangat bermanfaat bagi pengguna jika mereka mengalami kesulitan dalam menggunakan Shopee, Shopee juga menyediakan kategori pertanyaan dan daftar pertanyaan yang sering diajukan oleh calon pembeli.

15. Menu daftar dan login

Untuk mendaftar Shopee menyediakan kemudahan untuk mendaftar dengan email atau facebook, hal tersebut sangat bermanfaat bagi pengguna dengan memudahkan pendaftaran. Lalu fitur login tersedia login melalui SMS atau facebook yang juga bermanfaat bagi pengguna.

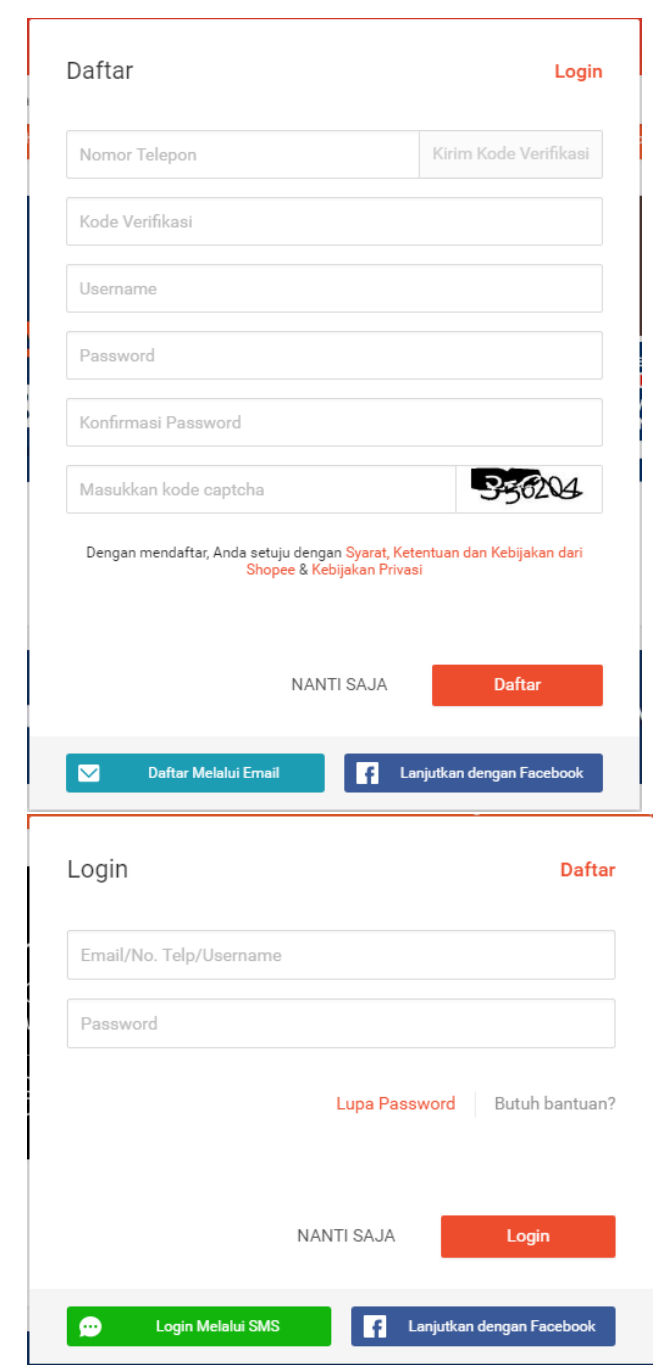

\section{Lupa password}

Fitur lupa password disediakan oleh Shopee agar memudahkan pengguna jika mereka lupa password akun Shopee. Fitur ini akan mengatur ulang password dengan mengirimkan kode verifikasi melalui nomor telepon pengguna

\section{Kesimpulan}

Berdasarkan pembahasan diatas mendapatkan hasil bahwa kualitas website Shopee menurut persepsi para penggunanya dari berbagai penelitian dan metode yang digunakan yaitu WebQual 4.0 dan IPA, website Shopee tergolong dalam kategori baik tetapi masih harus memperbaiki berbagai fitur maupun tampilan website-nya agar website lebih nyaman dan aman digunakan sehingga penggunanya betah untuk berbelanja online menggunakan Shopee sesuai dengan atribut WebQual 4.0 dan IPA. Penilaian Usability yang dilakukan dari berbagai penelitian menggunakan metode Nielsen juga menunjukkan bahwa Usability website Shopee masih memerlukan perbaikan karena adanya masalah pada fitur yang membuat penggunanya kurang nyaman 
dalam mengakses website Shopee, tetapi dari segi menu, transaksi atau penggunaan warna tampilan website masih tergolong baik sehingga masih banyak pengguna yang menyukai berbelanja online di Shopee. Akan lebih baik jika website Shopee dilakukan perbaikan dari segi kualitas dan Usability agar penggunanya lebih banyak dan tetap betah berbelanja menggunakan Shopee.

\section{Daftar Pustaka:}

Anonim. "10 Usability Heuristics by Nielsen ; Lazada and Shopee Review".

E. M. Landaoe and P. K. Sari. (2018): Analisis Kualitas Website E-Commerce Pada Website SHOPEE.CO.ID di Indonesia Dengan Menggunakan Metode WebQual 4.0, eProceeding Manag., vol. 5, no. 3, pp. 2988 2995.

F. Margaretha. (2017): Analisis Hubungan Antara Motif Dengan Tingkat Kepuasan Pengguna Aplikasi Shopee Sebagai Media Berbelanja Online PAD SHOPEEHOLICS di Kota Samarinda, eJournal Ilmu Komun., vol. 5, no. 4, pp. 26-40.

G. H. Akbar. (2017): Analisis perbandingan tingkat usabilitas pada website belanja online di indonesia (studi kasus: tokopedia, buka lapak, shopee), Pros. Semin. Nas. Teknol. IV, vol. 2598-7410, no. November, pp. 60-68.

L. Zulfa and R. Hidayati. (2018): Analisis Pengaruh Persepsi Risiko, Kualitas Situs Web, Pembelian Konsumen E-Commerce Shopee Di Kota, vol. 7, pp. 1-11.

M. Ichsan, M. Pradana, and M. Ichsan. (2018): Analysis of An Indonesian E-Commerce Website: Gap Between Actual Performance and Users 'Expectation, vol. 6, no. 2016, pp. $65-75$.

N. Rahmah. (2016): Persepsi Mahasiswa Terhadap Online Shop (Studi Deskriptif Tentang Persepsi Mahasiswa Surabaya Terhadap Online Shop Shopee), p. 2016.

R. Harminingtyas. (2014): Analisis Layanan Website Sebagai Media Promosi, Media Transaksi dan Media Informasi dan Pengaruhnya Terhadap Brand Image Perusahaan Pada Hotel Ciputra di Kota Semarang. J. STIE Semarang, vol. 6, no. 3, pp. 38-44.

R. Mardatilla, A. Usyanti, and H. Aryadita. (2017): Pengaruh Kualitas Layanan Terhadap Kepuasan, Kepercayaan dan Loyalitas Pelanggan Pada E-Commerce (Studi Kasus : Berrybenka), J. Pengemb. Teknol. Inf. dan Ilmu Komput., vol. 1, no. 12, pp. 1822-1832.

T. P. Darmawan and A. L. Yuliati. (2017): Analisis Kualitas Website Forum Jual Beli Online Shopee Di Indonesia, e-Proceeding Manag., vol. 4, no. 2, pp. 1883-1887.

W. Sastika. (2017): Analisis Kualitas Layanan
Dengan Menggunakan E-Service Quality Untuk Mengetahui Kepuasan Pelanggan Belanja Online Shoppe (Studi Kasus: Pelanggan Shopee Di Kota Bandung 2017).

Y. Ichsani. (2018): Evaluasi Performa Usability Situs-Situs Web Perguruan Tinggi Negeri Di Indonesia Yang Terakreditasi ' a' Tahun 2013 Serta Perbandingan Kondisi Situs Web Tahun 2014 Dan 2017, J. Tek. Inform., vol. 10, no. 2, pp. 93-108. 
Volume 6, Edisi 1, November 2019

$\mathbf{7 0} \mid \mathrm{H}$ a $\mathrm{l}$ a $\mathrm{m}$ a $\mathrm{n}$ 